\title{
Scientific progress in the production of monogastric in the first decade of the twenty-first century
}

\section{Fernando Guilherme Perazzo Costa $^{1}$, José Humberto Vilar da Silva ${ }^{1}$, Raffaella Castro de Lima ${ }^{1}$, Cleber Franklin Santos de Oliveira ${ }^{1}$, Valéria Pereira Rodrigues ${ }^{1}$, Sarah Gomes Pinheiro ${ }^{1}$}

${ }^{1}$ Programa de Pós-Graduação em Zootecnia da UFPB, Areia-PB, CEP: 58397-000

ABSTRACT - Significant progress in the area of animal production is due to the development of researches on genetics, environment, health, management and nutrition. The search for better management conditions that benefit animal welfare resulted in changes to the installation. The genetic improvement more productive animals has encouraged the number of searches to reduce the incidence of diseases, mainly of metabolic origin. The incorporation in products with higher bioavailability as industrial amino acid and organic minerals, the inclusion of products modifiers enteric of microflora as probiotic, prebiotic, symbiotic, nucleotides and exogenous enzymes, has benefited the use of nutrients are not well absorbed and often unavailable in the diet. Biotechnology latest as nutrition in egg and molecular biology has been used for the benefit of the increase animal productivity.

Key Words: amino acids, biotechnology, nutrition, phenomenal progress

\section{Progresso científico na produção de monogástricos na primeira década do século XXI}

\begin{abstract}
RESUMO - Progressos significativos na área da produção animal devem-se ao desenvolvimento de pesquisas nos campos da genética, ambiência, sanidade, manejo e nutrição. A busca por melhores condições de manejo que beneficiassem o bem estar animal provocou modificações nas instalações. O melhoramento genético visando animais mais produtivos tem incentivado o numero de pesquisas para redução da incidência de doenças, principalmente as de origem metabólica. A incorporação na ração de produtos com maior biodisponibilidade como aminoácido industriais e minerais orgânicos, a inclusão de produtos moduladores da microflora entérica como probióticos, prebióticos, simbióticos e nucleotídeos como também, o uso de enzimas exógenas, tem beneficiado a utilização de nutrientes antes pouco absorvidos e muitas vezes indisponíveis na dieta. Biotecnologias mais recentes como a nutrição in ovo e a biologia molecular têm sido utilizadas para benefício da maior produtividade animal.
\end{abstract}

Palavras-chave: aminoácidos, biotecnologia, nutrição, progresso fenomenal

\section{Introduction}

In recent years, monogastrics production showed significant growth with excellent results in the agricultural sector, making it a highly productive segment in the domestic and international market.

In nearly fifty years between 1961 and 2007, the world production of poultry meat (mainly chicken meat) almost tenfold with an increase around $900 \%$. For swine production, there was increase over 300\% (Poultry Industry, 2009).

In Brazil, according to the Brazilian Poultry Union (BPU) meat broiler production was of 5.977 and 10.962 million tons in 2000 and 2009, respectively, which shows an increase of approximately 55\%. Concerning the swine production, the increase in slaughter average weight contributed to the meat supply of cattle industry increased by 7\% reaching 2,873 million tons in 2009, 187 thousand tons more than the previous year (Abipecs, 2009).

Projections for 2018, according to the Organization for Cooperation and Economic Development (OCED) estimate the world production of poultry meat (mainly broilers) amounting to 120,3 million tons and accounting for $38.26 \%$ in the production of the three main meat types, while the swine will account for $38.14 \%$ with production of 119,9 million tons.

The evolution in the coefficients of broilers production clearly demonstrates the progress obtained in the area. According to UBA, a chicken to 105 days of age had average weight of $1.5 \mathrm{~kg}$ and 3.5 feed conversion in the thirties. Currently, broilers to 42 days weighs $2.8-2.9 \mathrm{~kg}$ and 1.6 feed conversion. In swine, technological advances have provided the appearance of animals with low fat, calories 
and cholesterol when compared to 25 years ago. Growth has no stop and continues to the areas of ambience, management, genetics, health and nutrition.

In genetics and nutrition, advances have been significant. Facilities and equipment have gone through many changes, positively influencing on animal performance but with a new approach focused on animal welfare.

In this context, the objective of this review is to address about the main scientific advances in the production of monogastric animals, particularly poultry and swine.

\section{Ambience, management, genetics, health and nutrition}

Successful production of poultry and swine is associated with advances verified in pillars of ambience, management, genetics, health and nutrition. Positive results would not have been possible if any of these sections had not followed the development speed imposed by the agricultural sector.

It was observed over the years that the so-called conventional facilities, with open houses, natural ventilation, hand-feeders and hand-drinkers, started to be replaced by modern facilities. Today, we find semiconditioned or conditioned environments, through the use of ventilators, nebulizers, exhaust fans, cooling systems, automatic feeders and drinkers from nipple type. We have also the ease of control for temperature, humidity and ventilation through electronic monitoring with computerized records, facilitating the control of climatic variations. Concern for the welfare of commercial hens made the European Union to impose minimum standards for breeding, so that poultry in conventional cages will be banned in European countries and only furnished cages or alternative systems will be allowed in poultry from 2012.

Furnished cages are relatively new in egg production and allow poultry to show natural behaviors, as they have access to nests, perches, places to sand bath, more space (at least $750 \mathrm{~cm}^{2}$ per bird) to move or escape of the more aggressive or dominant bird, keeping the same economic and hygienic standards of conventional cages (Vits et al., 2005).

Currently there is a considerable amount of researches to develop furnished cages or modify conventional cages in order to meet the needs of welfare. Among these are observed the incorporation of perches to improve bone strength, the use of whole divisions between cages to reduce damage to feathering; abrasive tape or paint at the trimmer base to allow birds to reduce their nail size and consequently skin lesions while feeding; area for nests and sand baths (Vitz et al., 2005; Rocha et al., 2008).
The progress of genetics over the years has contributed significantly to the results in animal performance obtained nowadays. Knowledge of quantitative genetics combined with the use of computational and statistical techniques have ensured the continuous genetic progress in all production traits.

As an example, we can cite the genetic improvement occurred in pigs' production. According to information cited by Roppa (1999), pigs had 40 to $45 \%$ of lean meat in the carcass and 5 to $6 \mathrm{~cm}$ of backfat thickness in the mid-20th century while at the end of the nineties numbers has changed to 58 to $62 \%$ of lean meat and only 1.5 to $1 \mathrm{~cm}$ backfat thickness.

Developed by Embrapa, light pig strains are a market proposal that offers producers, animals with large amounts of lean meat, reduced backfat thickness and lower intake food to reach slaughter weight $(115 \mathrm{~kg})$. According to Embrapa (2004), the light swine has 31\% less fat than other strains, $14 \%$ fewer calories and $10 \%$ lower cholesterol levels than it was 30 years ago.

In poultry, a study by Havenstein et al. (2003) show that $85-90 \%$ of the improvements made in the broilers performance were related to the selection process. Through genetic improvement was possible to develop commercial strains of high productivity and specific productive traits to a particular business purpose.

However, advances in technology have increased the broiler a considerable rate of body growth and therefore their metabolic activity, requiring greater performance of the cardiovascular system and promoting the emergence of metabolic disorders such as the pulmonary hypertension syndrome (ascite) and sudden death. Locomotor problems have also been a concern in the poultry industry due to the rapid animal growth on a skeletal system still under development.

Fortunately, studies evaluating the interaction between the strain's growth curve, feed nutrient levels and temperature have shown excellent results and have been implemented in order to minimize the incidence of such disorders and thus, reduce mortality and carcass condemnations in slaughterhouses.

Concerning the Brazilian poultry genetic material, this left some time to be exclusively focused on the internal market. Today we are an export platform for several countries, including Africa, Americas, Asia and more recently, Europe (Poultry industry, 2010).

This niche of activity - the export of fertile eggs - is a segment that is growing year by year. According to information from the Apinco and those published by the 
Avisite, shipments of fertile eggs used for the cut production increased 32.6\% in 2009 in comparison with 2008. Are almost 143 million units exported in the year against 108 million in the previous year (Avicultura Industrial, 2010).

For a long time the prevention and control of diseases is one of the major concerns in poultry and swine. Increase in the adoption of sophisticated biosafety programs began to occur in 90's from the establishment of large-sized explorations and with more complex concepts of production flow (Barcellos et al., 2008). Due to the opening of important international markets for swine and poultry sector, health concerns intensified and with the international requirements of exporting countries, the biosafety programs were consolidated as a key to the intensive production systems of monogastric animals.

Currently the only management practice capable of maintaining commercial farms free or controlled for the presence of infectious agents of economic impact is the biosecurity.

In industrial production, a biosecurity program can be defined as the planning and implementation of a set of guidelines and operational standards whose primary purpose is the plots protection against the entry of any pathogenic microorganism, whether virus, bacteria, fungi, protozoa or even endo- and ectoparasites (Filho \& Patricio, 2004).

Studies on nutrigenomics has investigated interactions occurring between genetics and nutrition, ie, how the phenotypic expression of a genotype can be modified by nutrition. This suggests that, in addition of being responsible for the growth and influence animal health, nutrition can regulate gene expression by hormonal action.

The nutrigenomics provides an understanding of how nutrition affects the growth and health of animals to alter gene expression or phenotypic manifestation of the individual. The goal is to provide nutritional and management strategies to control processes associated with gene expression. This science also promises to set new nutritional strategies and techniques to alter gene functions that improve health and animal productivity. When associated with new strategies for genetic selection, it can be expected to have a significant impact on the way to interpret the animal production and management (Rutz et al., 2009).

In the nutrition area, one of the greatest advances has been the settings of nutritional requirements for monogastric animals. Currently we have available, Brazilian tables of nutritional requirements for poultry and swine (Rostagno et al., 2005) and more recently for quails (Silva \& Costa, 2009).
Whereas for many years that this information was acquired from foreign tables such as NRC (1994) not being ideal for tropical conditions in Brazil, today we can say that we have important information for better expression of animal performance as they bring data in line with the current need in nutritional terms.

We also have biotechnologies such as in-egg nutrition, used to improve the nutritional status of birds still in their embryonic stage, and the molecular biology in order to increase the animal health resistance, through the selection of quantitative genetics.

Another important point that deserves highlight is the rational use of additives in the diet, with the aim of helping the animal to make more efficient use of nutrients in foods, thereby increasing productivity. Among the additives, it can be highlighted the industrial acids, organic minerals, antibiotics, probiotics, prebiotics, symbiotic, enzymes and exogenous nucleotides.

The use of exogenous enzymes for feeding significantly increased in recent years, mainly due to the rising costs of traditional raw materials which have led the search for alternative ingredients such as barley, oats, rice, wheat, among others.

The addition of enteric microflora modulators as probiotics, prebiotics and symbiotic as an alternative to antibiotics has gained ground in the food formulation due to the new demands of the global market. Ingredients with higher bioavailability as industrial acids and organic minerals have been used due to their better absorption and lower waste excretion, reducing environmental pollution.

\section{Amino acids}

The formulation of diets for poultry and swine has been based for years on the concept of crude protein. As a result, the presence of larger amounts of aminoacids in relation to the actual nutritional requirements of animals promoted an unbalanced diet. The greater economic viability for the purchase of industrial amino acids has facilitated the formulation of diets based on amino acids, with a lower protein level and amino acids closer to the poultry needs.

With the increasing of amino acids in the industrial market (in the 50s), nutritionists have been able to formulate diets in order to meet the single needs for essential amino acids. According to Penz (1996), the use of industrial amino acids not only aims to reduce nitrogen excretion as well as reduce the high cost of production due to a reduction in the crude protein level in the diet. According to Parsons \& Baker (1994), among the most important amino acids in the productive chain of poultry and swine, lysine, methionine + cystine, threonine, tryptophan and arginine are highlighted. 
Over the past 20 years with the availability of amino acids for industrial use in animal nutrition, several surveys have been conducted in order to define the requirements of essential amino acids in the nutrition of poultry and swine. Given this, it started to be discussed the concept of ideal protein.

According Sakomura \& Rostagno (2007), the ideal protein can be defined as the exact balance, without excesses or deficiencies of all the amino acids necessary for animal maintenance and maximum protein deposition. This reduces the use of amino acids as energy source and reduces nitrogen excretion.

Currently, it is recommended to formulate diets based on the ideal protein. Although the amino acid needs are different, their relationship is affected only by animal age, once according to weight (maintenance) and daily weight gain (protein deposition) there is the ideal protein set for each age (Rostagno et al., 2002). Theoretically, there should be only an ideal protein for each day of age of the animal, which would only be possible by applying equations to predict the daily requirements for maintenance and weight gain of each amino acid. From the practical point of view, relationships of the amino acid with lysine for 2 or 3 stages in the animal life are published, ie for the initial phase, growth and final phase.

Studies performed by Moraes et al. (2010) and Costa et al. (2010a), evaluating the best value for digestible valine: digestible lysine ratio for broilers at early and growth stages, respectively, estimated the best value in $85 \%$ and $76 \%$ for better broilers performance.

A study involving the use of valine, isoleucine and glycine in diets with reduced protein in feed for broilers showed that only the diets supplemented with valine promoted best performance results in pre-initial phase (Costa et al., 2009a). Goulart (2010) using the same amino acid in feeding broilers, concluded that reducing protein in diets by use of industrial amino acids improved the efficiency of protein deposition and decreased nitrogen excretion, but increased body fat deposition.

As dietary protein is reduced with the supplementation of industrial amino acids, the adjustment of the optimum ideal relationship of these components becomes increasingly important. The limiting order of amino acids in the diets is what specifies which amino acids are necessary to maintain the optimal balance (Sakomura \& Rostagno, 2007). The basic idea of this concept is that animals require amino acids in balanced amounts to achieve optimum performance. Amino acids that are absorbed in excess of the first limiting are oxidized and excreted as nitrogen compounds. According to McLeod (1997) excess amino acids degradation in food has a high energy cost for animals. Diets with high protein content provide less liquid energy content than diets with low protein levels formulated based on the ideal protein. Therefore, adjusting amino acids in the diet according to the ideal protein there is maximizing nitrogen use in the diet and decreased excretion.

According to Suida (2001), the values of amino acids must to be expressed in terms of digestible amino acids and no more in total amino acids; therefore the requirement is not protein but specific amino acids and non-specific nitrogen for the synthesis of nonessential amino acids. The minimum excess of amino acids in the diet is one way to reduce the excessive nitrogen excretion, which is becoming a serious problem in countries with intensive livestock production.

Costa et al. (2010b) evaluating diets formulation based on digestible amino acids in relation to the formulation based on total amino acids for quails of 1 to 21 days, verified better feed conversion when diets were formulated based on digestible amino acids. However, Robinson et al. (2010) found no significant differences in performance of quails at 22 to 42 days in comparison with formulations based on total and digestible amino acids.

Although a large number of studies evaluating diets low in protein, there is controversy about the results. According to some authors, protein reduction in diets supplemented with industrial amino acids for poultry leads to a performance reduction for them (Pinchasov et al., 1990; Costa et al., 2001; Bregendahl et al., 2002). However, other authors show that it is possible to reduce the dietary protein without compromising poultry performance when supplemented with amino acids, since essential amino acids requirement is met (Han et al., 1992; Silva, 2004; Nagata et al. 2005 a, b; Dean et al., 2006).

Lima Neto (2010) evaluated the effect of levels of digestible threonine and ratios of threonine:lysine and threonine:glycine on performance, body composition and intestinal morphometry of broiler chicks during the preinitial phase. It was observed that increasing the threonine level to the limit of $0.815 \%$ with 0.68 threonine:lysine and 0.40 threonine glycine provided improved performance, even with $5.1 \%$ reduction in crude protein in relation to the control food. The author also noted a performance decrease, which was minimized by increasing levels of digestible threonine and total glycine+serine to $0.88 \%$ and $2.23 \%$ respectively, with 0.70 threonine:lysine and 0.39 threonine:glycine. According to this author, these findings reinforce the theory of ideal protein, where the reduction in 
dietary CP combined with industrial amino acid supplements brings not only economic but also environmental and zootechnical benefits by better amino acids balance, maximizing the retention of nitrogen and energy and reduction of nutrients losses which are not absorbed. However, warns for the performance loss caused by intense decreases, even when there is supplementation with industrial amino acid.

Araújo et al. (2001) working with the objective of evaluating broilers performance fed on formulated diets based on crude protein or ideal protein found that ideal protein resulted in better weight gains, increased feed intake and no effect on feed conversion. In contrast, Hussein et al. (2001) when comparing diets with 23 and $17.7 \%$ crude protein supplemented with essential amino acids, found greater weight gain, increased feed intake and improved feed conversion with reduction of crude protein, regardless of amino acids addition.

Similar effect was cautioned by Bregendahl et al. (2002) when studying diets with high (23.99\%) and low (18.53, $18.48,18.66$ and $18.63 \%$ ) crude protein content and higher essential amino acids concentration (15, 30 and $45 \%$ above levels recommended by NRC, 1994). These authors, however, observed that feed intake decreased linearly with increasing concentration of essential amino acids in the diets.

For young swine, glutamine is considered an essential amino acid since body is not capable of synthesizing it in sufficient quantities to meet its nutritional needs, especially during the weaning of piglets. Positive effects of its use can be observed in the transition between gestation and lactation, when the loss of muscle mass in primiparous sows and longer estrus after weaning can be minimized with glutamine supplementation in the diet.

Studies performed at the Universidade Federal de Viçosa evaluated the performance and indexes of diarrhea in piglets weaned at 21 days, fed on diets containing a product based on glutamine + glutamic acid (AminoGut ${ }^{\circledR}$ ) or $4 \%$ plasma, and found positive effect of adding glutamine on weight gain, feed conversion and index of diarrhea. The recommended level of AminoGut in the diets of piglets was $0.8 \%$ (0.68 to $0.93 \%$ ) (Lopes \& Rostagno, 2007).

Carvalho et al. (2008) evaluating glutamine supplementation in primiparous sows in the final third of gestation and lactation on prolificacy at the next birth concluded that matrices who were supplemented with AminoGut ${ }^{\circledR}$ showed respectively $0.7 \%$ piglets born alive and piglets $3 \%$ total more born in the second parturition when compared with the first one. Kikuchi et al. (2009) evaluating the influence of pure glutamine supplementation or associated with glutamic acid (AminoGut ${ }^{\circledR}$ ) on the characteristics of broilers performance from 1 to 42 days old, state that feed conversion can be improved when there is AminoGut ${ }^{\circledR}$ inclusion for 1 to 21 days.

The potential of glutamine in the immune response was investigated by Yi et al. (2005). The authors found that piglets challenged with Escherichia coli K88 + showed lower weight gain and worse feed conversion and that diet supplementation with glutamine allowed the recovery of performance indicators.

According to Batterham (1994), not only essential amino acids but also those non-essentials should be included in the ideal protein "in a correct proportion." Cole and Van Lunen (1994) suggested that to provide the ideal protein, it would be necessary to provide a balanced mix of essential amino acids with enough nitrogen for synthesis of nonessential amino acids.

Costa et al. (2010c) evaluating the effect of crude protein and in relation to essential:non-essential amino acids in broilers from 8 to 21 days of age found that for every $1 \%$ increase in crude protein in the diet followed by a reduction in essential amino acids:non-essential, there was reduction in feed intake and improved feed conversion, recommending $19 \%$ crude protein and 52:48 essential:nonessential amino acids for best performance. For broilers of 22 to 40 days, Costa et al. (2010d) observed that for every $1 \%$ increase in protein levels and reduction in essential:nonessential amino acid ratio, there was reduction on feed intake and weight gain, suggesting $16.5 \%$ crude protein and about 49:51 ration in this stage.

A study carried out by Costa et al. (2009b) to evaluate the effects of crude protein and essential:non-essential amino acids on the carcass of broilers at 40 days old, observed that the crude protein in the diet when reduced to 16.5\% with 49:51 essential: non-essential amino acids ratio did not alter the carcass performance parameters.

According to Han et al. (1992), chicks of 1 and 21 days fed on corn and soybean meal with $19 \% \mathrm{CP}$ and supplemented with methionine, lysine, threonine, arginine and valine, as well as non-essential amino acids and glutamic acid (Glu) had similar performance to those fed on a control diet containing 23\% CP. From 22 to 42 days of age, poultry fed on $16 \%$ CP and supplemented with the same amino acids had similar performance to those who received the control diet with 20\% CP without difference in body fat content.

Antibiotics, probiotics, prebiotics and symbiotic

The search for maximum feed efficiency and high animal productivity encouraged, over the years, the use of additives in feed for poultry and pigs. Among the most varied existing 
additives, antibiotics, probiotics, prebiotics and symbiotic have in common the ability to modulate the intestinal microbiota aiming to improve animal performance by increasing the feed efficiency.

Antibiotics are chemicals produced by microorganisms with the ability to inhibit the reproduction or destroy other microorganisms by interfering with some metabolic pathway of the target microorganism.

According to Dibner \& Richard (2005), the first references indicating the antibiotics effects on the performance of poultry and swine back to 1946 and 1950 . After the use of an experimental compound of feed for poultry containing tetracycline, it was observed that poultry had a higher growth rate than the control group. Other effects were also observed such as improvement in egg production and increase in the number of animals per litter of swine (Edqvist \& Pedersen, 2001).

Since then, antibiotics have to be included in animal production systems, especially poultry and swine. Surveys show the positive effects of antibiotics as growth promoters.

Stutz \& Lawton (1984) working with Hubbard male chicks, tested several antibiotics in practical diets based on corn and soybean meal and observed that the antibiotics bacitracin, penicillin, chlortetracycline, virginiamycin, lincomycin, bambermycins and carbadox improved weight gain and feed efficiency and, reduced significantly the ileum weight and the number of Clostridium perfringens in the poultry's ileum. Zuanon et al. (1998) found greater weight gain and feed conversion in poultry from 1 to 21 days fed on feed containing avoparcin compared to the control diet. Loddi et al. (2000) studying the use of probiotic and antibiotic on broilers performance showed higher body weight and weight gain for males which received antibiotic supplementation when compared to those nonsupplemented. Boratto et al. (2004) evaluating the syndicated use of antibiotics (virginiamycin and nitrovin), probiotic and homeopathy in broiler raised in comfortable environment and inoculated or not with Escherichia coli, found that antibiotics promoted better feed efficiency. Utiyama et al. (2006) evaluating the effects of antimicrobial zinc bacitracin and olaquindox in addition to probiotics, prebiotics and plant extracts on the intestinal microflora and performance of weanling pigs, found that microbial agents have improved the daily gain at 15 to $35(+22 \%)$ and 1 to $35(+21.4 \%)$ days of trial.

According to Bellaver (2000), for swine, the use of promoters antimicrobials is able to increase the daily weight gain around $21 \%$ in the early stages and $10 \%$ in the growth phase compared with feed without these agents.
Antibiotics effect is visible in researches on animal nutrition, however, the mechanism by which they act as growth promoters have not been fully clarified. It is believed that changes in flora promoted by its use reduce a particular group of bacteria sensitive to this antibiotic, benefiting other more resistant organisms.

According to Haese \& Silva (2004), the growth stimulatory effect that antibiotics have on animals can be explained by the following hypotheses: inhibition of specific microorganisms, improvement on the desirable microflora:undesirable microflora ratio, increased starch digestion, reduction on the production of enterogenous toxins, reduction of intestinal mucosa cells renewal, increased number of bacteria necessary for protein synthesis, reduction of bacteria that consume B vitamins, thinning of the small intestine wall, increased blood supply and nutrient absorption, increased feed intake, weight gain and better feed conversion, mortality reduction.

However, greater consistency is necessary in research results demonstrating the effectiveness of certain agents to stimulate the animal performance.

In recent years, the indiscriminate use of antibiotics in farm animals is worrying the world's population. Some situations have confirmed that attention would turn to their use. In 1996, with the emergence of the bovine spongiform encephalopathy or "mad cow disease", it was found that the cause of this pathology in cattle have been the consumption of meat flour from sheep suffering from other encephalopathy known as scrapie. Shortly after, in 2000, it was found in Belgium the chicken meat contamination by a dioxin.

These events encouraged bans by countries of the European Union, demanding antibiotics exclusion in animal feed. Thus, from 1st January 2006, the European Economic Community imposed the ban on the use of antibiotics as growth promoters in animal feed (Muralolli, 2008), with the concern that these additives can induce resistance to important pathogens to the humans.

Many additives used in the past are currently banned such as tetracycline, penicillin, chloramphenicol, sulfonamides systemic, furazolidone, nitrofuzarona and avoparcin. In Brazil, the following products are still authorized: acid 3-nitro acid arsalinic, avilamycin, colistin, flavonicin, loncomicin, tylosin, virginiamycin, bacitracin, spiramycin and enramycin (MAPA, 2004).

The analysis of results arising from the banning of some antimicrobial additives made by some European Union countries like Sweden and Finland contains relevant information about the use of these products. After a few 
years without the use of these additives was observed 6\% decline in the feed conversion, $5 \%$ reduction in weight gain, $4 \%$ increase in the use of medicinal products intended for curative treatment, 12 to $30 \%$ reduction in gross profit margin and $1.6 \%$ increase in total mortality of animals (Murarolli, 2008).

Assessing the possible economic losses caused by antibiotics withdrawal in animal feed, researchers began to look for other ways to benefit the animal productivity considering the new demands of the global market. One of them would be the increased use of probiotics, prebiotics and synbiotics not as substitutes but as an alternative to antibiotic growth promoters by benefiting the health host, not letting residues in animal products and not favoring drug resistance.

Probiotics are additives consisting of beneficial live microorganisms supplemented in the diet in order to colonize the gastrointestinal tract by means of competitive exclusion, ensuring better animal health and more efficient use of nutrients in the diet. In addition to competitive exclusion, there is also direct antagonism and enhancement of humoral immune response (Costa et al., 2008a).

The yeasts Saccharomyces cerevisiae have been one of the most studied probiotic microorganisms in swine diets. The main effect of this probiotic in swine occurs in the small intestine, involving the stimulation of intestinal enzymes (disaccharidases), the antiadhesive effect against pathogens, inhibition of toxin production and antagonism against pathogens (Pupa, 2008).

Mountzouris et al. (2007) evaluating the efficacy of a probiotic containing Lactobacillus, Bifidobacterium, Enterococcus and Pediococcus strains on the performance and modulation of cecal microflora composition of broilers, found that the probiotic promoted performance results (feed conversion and weight gain) similar to those presented by poultry fed on a diet containing only antibiotic (avilamycin). The probiotic also promoted the modulation of cecal microflora, benefiting the proliferation of beneficial bacterial such as Bifidobacterium spp., Lactobacillus spp. and thus stimulating the metabolic activity of the cecal microflora.

Therefore, it is observed the valuable use of probiotics in animal feed with beneficial actions similar to those of antibiotics but eliminating those undesirable, such as bacterial resistance and residues in the carcass.

Prebiotics are non-nutrient ingredients, non-digestible, which beneficially affect the host, selectively stimulating the growth and activity of one or more species of beneficial intestinal bacteria. This effect is caused mainly by selectively stimulating the growth and or activity of a limited number of bacteria in the body. As an example, there is the mananoligosaccharides (MOS) - which are extracted from the cell wall of Saccharomyces cerevisiae and the fructoligosaccharides (FOS) - synthesized from Aspergillus niger or Aureobasidium pullulans. There are also those glicoligosaccharides and galactoligosaccharides (Costa et al., 2008a).

The change of intestinal flora caused by the use of prebiotics may occur in two ways: by providing nutrients for desirable bacteria or through recognition by pathogenic bacteria and binding sites to the oligosaccharides as the intestinal mucosa, thus reducing the undesirable intestinal colonization, resulting in a lower incidence of infections and better integrity of the intestinal mucosa, making it capable of performing its functions (Iji \& Tivey, 1998).

Sims et al. (2004) worked on diets containing 0.1\% MOS and $55 \mathrm{mg} / \mathrm{kg}$ bacitracin until the 6 th week and $0.05 \%$ MOS and $27.5 \mathrm{mg} / \mathrm{kg}$ of bacitracin from 7 th to 18 th weeks of age and noted that turkeys treated with bacitracin had longer villi throughout the intestine at 18 weeks.

The MOS modify the intestinal flora, reduce mucosa turnover, modulate the immune system (Shane, 2001), improve broilers performance (Sims et al., 2004) and increase intestinal villi's height (Iji et al., 2001).

Albino et al. (2006) evaluated the performance of courts and broilers fed on diets containing MOS and the feasibility of replacing antibiotics by alternative additives. Three types of additives were used: a growth promoter (avilamycin) and two prebiotics (MOS) with different yeast concentrations, called standard MOS and high concentration MOS, which were included in the diets either isolated or associated. It was found that the addition of avilamycin and standard MOS, either alone or in combination, provided beneficial effects on weight gain of poultry from 1 to 42 days old. Authors concluded that prebiotics based on MOS can replace the antibiotics avilamycin in diets for broilers without impairing production.

Using laying quails, Costa et al. (2008b) found higher values of egg production and egg mass in poultry fed on a diet containing $0.05 \%$ Bio-Mos. However, when it increased supplementation of Bio-Mos to $0.10 \%$, performance was higher than presented by poultry subjected to the control diet, but lower than those fed on $0.05 \%$ Bio-Mos. A probable explanation lies in the fact that quails show faster food passage rate and higher feed intake relative to body weight compared to broilers. The presence of higher amount of oligosaccharides with $0.10 \%$ dietary supplementation may 
have further increased the speed of intestinal transit, reducing nutrients digestibility in relation to diet with 0.05\% Bio-Mos.

Oliveira et al. (2009) evaluated the effect of diets with MOS and enzyme complex on performance, intestinal morphology and quality of poultry litter at 42 days of age and found that the addition of MOS or enzyme complex to the diets increased the villi's height and perimeter in jejunum and ileum and reduced ammonia volatilization. The reduction in ammonia volatilization with the MOS addition to diets possibly occurred because of low molecular weight carbohydrates such as oligosaccharides, which are completely digested in the intestine, having the increase number of Lactobacilli and Bifidobacterium and the reduction in Clostridia and Enterobacter, which produce ammonia, as a consequence. Silva et al. (2009) evaluated the performance of broilers reared under different temperatures and fed in pre-initial phase on a diet containing or not yeast extract and/or prebiotics and observed that the prebiotic inclusion in the pre-initial feed results in greater weight gain in poultry raised in low temperature environments at the end of 21 days of age and increases the creation feasibility regardless of the temperature used.

Evaluating prebiotics for swine in rearing phases (phase I) and finishing (phase II), Bell et al. (2009) compared the following diets: control (no additives), $0.2 \%$ prebiotics ( $0.1 \%$ MOS and $0.1 \%$ fructoligosaccharides); 15 ppm of apramycin; $0.2 \%$ prebiotics $(0.1 \%$ MOS and $0.1 \%$ fructoligosaccharides ) +15 ppm of apramycin). Difference was found only for feed conversion in phase I for the animals that received the diet with probiotics compared to treatment with apramycin + prebiotics. For the other experimental periods there were no differences for any of performance variables examined. Authors suggest that the absence of positive results when evaluating the use of probiotics as growth promoters is due to their low inclusion in the diets to the significant amount of oligosaccharides present in cereals and soybean in the basal diet and to the good health and animals' age. Still in the same study, there was greater loin area in swine fed on prebiotics, presenting $13.48 \%$ higher when compared to swine fed on the control diet. This result, according to the authors, can be explained by prebiotics (MOS + fructoligoccharides) have favored the intestinal flora, thus enabling better protein utilization for muscle development.

The combination of probiotics and prebiotics is called symbiotic and represents a new concept in the use of additives in diets for poultry (Awad et al., 2009; OviedoRondón, 2009). In this composition, probiotic bacteria are produced and mixed with a substrate that serves as its protector and feeder, improving the survival and establishment of beneficial bacteria in the digestive tract.

The interaction between probiotic and prebiotic (symbiotic) can favor the probiotic adaptation to the prebiotic substrate enhancing the effect of both. These additives have trophic actions in the gastrointestinal tract, favoring the mitotic process in region of crypt-villus, increasing cell number and villi size, since by inhibiting the excessive proliferation of pathogenic bacteria in the intestinal tract, reduce the production of toxics metabolites that affect the intestinal epithelium impairing nutrients absorption (Junqueira et al., 2009).

Junqueira et al. (2009) observed the addition effect of antibiotic, probiotic, prebiotic and sodium gluconate for swine in the period 28 to 142 days of age, corresponding to the nursery, growing and finishing phases and concluded that among additives, the symbiotic was more efficient as it promoted the best results in weight gain and feed conversion. Awad et al. (2009) evaluating the inclusion effect of probiotic and symbiotic on performance, organ weights and intestinal histomorphology in broilers found that poultry fed on diets containing the symbiotic Biomin IMBO (combination of the strain E. faecium DSM 3530 and prebiotic) had a body weight, daily gain, carcass yield and feed conversion ratio significantly higher when compared with poultry fed on diets containing probiotics and control diet (no additives).

\section{Exogenous enzymes}

The use of exogenous enzymes is an important tool in the search for better zootechnical indexes in poultry and swine areas, also promoting reduction in production costs and therefore higher investment income (Brito, 2010). When added to diets, enzymes reduce the role of anti-nutritional factors acting as digestion enhancers.

Initially, enzymes were used in diets containing ingredients with high amounts of non- amide polysaccharides such as wheat, rye, triticale, barley and oats. However, researches have shown the possible use of enzymes complexes to diets based on cereals such as maize, sorghum and soybean meal with the goal of increasing the utilization of starch and protein (Rodrigues et al., 2002).

It has been found in recent decades an increasing number of researches involving the use of enzymes in the nutrition of poultry and swine (Selle \& Ravindran, 2007). The main objective is the manipulation of existing conditions in the digestive tract and improving ingredients nutritional value (Meng et al., 2005). Its use has also been linked to better digestibility of alternative foods, energy sources and 
reduction of negative effects to the environment, with decrease of waste excretion (Murakami et al., 2007).

Lima et al. (2009a), evaluating the phytase (Ronozyme ( ) effect on the performance of commercial hens, used the following diets: $\mathrm{T} 1=0.35 \%$ available phosphorus (aP), $\mathrm{T} 2=0.25 \% \mathrm{aP}, \mathrm{T} 3=0.15 \% \mathrm{aP}, \mathrm{T} 4=\mathrm{T} 3+10 \mathrm{ppm}$ of phytase, $\mathrm{T} 5=\mathrm{T} 3+33 \mathrm{ppm}$ of phytase, $\mathrm{T} 6=\mathrm{T} 3+56 \mathrm{ppm}$ of phytase, and $\mathrm{T} 7=\mathrm{T} 3+80 \mathrm{ppm}$ of phytase. The authors observed that the inclusion of $80 \mathrm{ppm}$ of Ronozyme ${ }^{\circledR}$ in the diet with $0.15 \%$ available phosphorus showed excellent results in the diets of semi-weighted hens, with higher egg production, egg mass and feed conversion per mass and per dozen eggs. Regarding the economic analysis, Lima et al. (2009b) showed that increasing phytase supplementation improved gross margin, especially with the use of $80 \mathrm{ppm}$ of Ronozyme ${ }^{\circledR}$ surpassing by $22 \%$ the gross income relative to the control diet.

The effect of microbial phytase on protein/amino acid may be considered of practical interest and currently need to be quantified to enable its inclusion in feeds compounds. Studies have shown that with phytase addition in the diets, there is an improvement in the utilization of amino acids and proteins by animals (Campestrini et al., 2005).

Evaluating the use of phytase and xylanase in different fat levels (linoleic acid) in diets for broilers from 1 to 21 days old, Costa et al. (2010e) found that enzymes use improved weight gain and had less fat content when compared to diets without added enzymes. Therefore, this improvement may be compromised if a-low fat diet is used, suggesting that it should be ensured a minimum fat level added in diets based on corn and soybeans for enzymes effective use.

The effect of exogenous enzymes (Allzyme ${ }^{\circledR}$ SSF and Allzyme Vegpro ${ }^{\mathrm{TM}}$ ) was also observed in semi-heavy hens at the peak production (Costa et al., 2010f) and as a result had higher performance, similar production to poultry not supplemented with enzymes, but with improved gross margin.

\section{Organic minerals}

Minerals are important nutrients in diets for swine and poultry. They are needed for a variety of metabolic functions such as immune response, reproduction and growth (Larson, 2005). Due to its great importance in animal nutrition, questions about the recommendations in the tables of NRC requirements have intensified, with the concern that nutritional requirements were being met in proportions smaller than those required.

In an attempt to alleviate the problem, nutritionists have become used to using amounts of trace minerals above the recommendations suggested in the tables, however with the risk of having interactions among minerals, a fact that may reduce the availability of other minerals in the diet and increasing excretion to the environment.

Another factor associated with the use of inorganic trace minerals (zinc sulfate, sodium selenite, copper sulfate, etc.) is that when in the ionic form, they may complex with other dietary components (minerals, proteins, carbohydrates) hindering their absorption or making them unavailable to poultry (Pereira et al., 2009).

Considering this information, we have evaluated the use of organic minerals as food supplement for poultry and swine. Preference for the use of organic minerals instead of conventional inorganic sources is associated with the idea that organic sources are more bioavailable and therefore more easily absorbed and retained in the poultry's body.

Recent researches have shown that organic minerals (chelated or bound to specific molecules) do not suffer from competition by already having their own amino acids to enter the digestive tract, due to their binding way, the metallic mineral is chemically inert thus it does not interact with free metal ions (Oliveira, 2004).

According to Fernandes et al. (2008), organic minerals can improve production and reduce mortality and stress, as well as reduce excretion into the environment since they are absorbed and retained in the poultry's body. However, the results of its use are conflicting.

Tucker (2004) observed that organic mineral supplementation can improve the egg weight and production around $1 \%$, as well as promote $2 \%$ increase in egg mass. In a study developed by Stanley et al. (2004), it was found that eggs from hens fed on Sel-Plex were significantly heavier $(68.13 \mathrm{~g})$. With the increasing production development of high performance animals, nutritional requirements have increased and new microelements and forms of supplementation entered the production scenario. These minerals are essential nutrients for optimizing and maximizing animal performance (Rutz et al., 2007).

In swine, the best performance results were obtained when zinc, copper, iron and manganese were reduced in $30 \%$ of normal levels and added in the organic form (Fremaut, 2003). However, Burkett et al. (2005) found better results with $50 \%$ reduction in the levels of trace minerals.

In the research performed by Tucker (2004), supplementation of organic minerals (Bioplex minerals) in hens' diets resulted in a greater mineralization degree and higher density of eggs, increase in eggshell resistance and reduction in the number of broken eggs. 


\section{Nucleotides}

The study of nucleotides is necessary once they are able to act in replacement, maintenance and creation of immune cells such as intestinal cells, for example.

According to Rutz et al. (2006), the development of preinitial diets for poultry and swine and the advances in knowledge of digestive physiology and its relation to the immunity have created a new field, called immune-nutrition, which aims active Bionutrients supply to help in the early development of the gastrointestinal tract generating better productive results.

According to Tibbets (2004), the main benefits of nucleotides use in diets for animals include: increased efficiency in energy and nitrogen metabolism, increased villi maturation rate; improved intestinal morphology and higher nutrient uptake; optimization on functions of high growth rate tissues, improvement in immune response with reduction of intestinal disorders, increased flavor (flavoring agent) and increased weight gain.

The use of yeast extract as vegetable protein source in the early stages of production increases growth, feed intake and feed efficiency, in addition to the short- and long terms improvement of the intestinal morphology and animal health. According to Esteve-Garcia et al. (2007), during periods of intense development, nucleotides availability can limit maturation of tissues with rapid cell replication and low biosynthetic capacity, such as intestines, thus restricting the growth rate by the lower capacity of digestion and nutrient absorption.

Assessing the effect of using a yeast extract ( $\left.\mathrm{NuPro}{ }^{\circledR}\right)$ on performance and characteristics of broilers carcass, Rutz et al. (2006) found that performance was better when providing yeast extract, 1 to 7 and from 38 to 42 days of age, although carcasses have not been affected by treatments. Authors attributed the better performance of broilers to the increased villous: crypt, by the action of nucleotides present in yeast extract favoring the increase capacity of digestion and nutrients absorption. They also mention that the presence of inositol may have contributed to the increase in body weight since it is a natural growth promoter. Inositol is related with phospholipids, which are structural components of membranes.

A study performed with the addition of different levels of nucleotides in feed for broilers from 1 to 42 days of age found that it can be added up to $0.30 \%$ nucleotides in the feed of broilers without the addition of antimicrobial growth promoter and without altering serum cholesterol, triglycerides, HDL-cholesterol and VLDL-cholesterol. However, the use of feed with antimicrobial growth promoter and without nucleotides addition increases the levels of LDL cholesterol (“bad cholesterol”) - low-density lipoprotein (Cruz, 2008).

In commercial hens, yeast extract addition during the growing period did not influence the external and internal quality of eggs from hens fed on bran rice on the production phase (Biegelmeyer, 2009).

Weaning usually causes a decline in feed intake by piglets, which can result in intestinal villous atrophy with consequently reduction of the absorptive capacity. In this case, dietary supplementation with nucleotides may be a strategy to improve health and performance in the postweaning phase.

There are experiments with piglets in the nursery phase evaluating aspects of intestinal morphology in order to determine the effects of plant proteins containing specific strain yeast extract and peptides (Tibbets, 2004). It was observed a similar improvement in the ratio of villus height:crypt depth. The area of lamina propria and villi width were significantly lower than in the treatment with plasma.

\section{"In egg" nutrition}

In egg nutrition during pre-hatching is a recent practice in the poultry industry, which consists in the inoculation of nutrients into the amniotic fluid through a syringe, puncturing the embryonated eggshell, with the aim of improving the embryo nutritional status (Leitão et al., 2005). However, positive responses not only depend on the solution composition but also the volume and osmolarity of solution injected into the amnion (Ferket et al., 2005). From the 15th day of incubation the embryo begins to ingest the amniotic fluid (Klasing, 1998) and, consequently, present substances are also ingested. Furthermore, it has been demonstrated that the embryo has digestive enzymes (Sklan et al., 2003) that make nutrition being possible in this phase.

How is a current technique, little is known about levels and types of nutrients that can be used in the embryo nutrition. Levels and composition of nutrients in egg are often omitted (Uni et al., 2005). A line that can guide the search for nutrients to be used is the study of yolk sac composition. The yolk sac is the primary nutrition source of the chick (Burnham et al., 2001) and is directly connected with the immune function of the bird.

Some ingredients may be used for inoculation, in addition to the cecal microflora and vaccines:

- Glutamine: neutral amino acid present in higher concentration in muscle and plasma. Acts in $\mathrm{Na} / \mathrm{H}$ exchange in the plasma membrane, increasing of the ornithine activity on intestinal villi, stimulating its development; 
- Glucose and sucrose: are being tested for in egg nutrition by being extremely important in the final stage of embryonic development (Uni et al., 2005) for glucose production, a key ingredient in the transition of chorionallantoid for pulmonary breath. Inoculation of these carbohydrates can increase the energy available to the embryo raising glycogen reserves, decreasing the use of muscle proteins, thus contributing to better bird performance;

- Linoleic acid: greater energy source of the embryo (lipids). Linoleic acid must be present in the fertile egg yolkin in order to produced chick with good quality;

- Vitamins: damage the transfer to the egg if it is deficient in the matrix. The transfer efficiency of vitamins from the diet to the eggs is considered as very high for vitamins: A (linked to cardiovascular development), riboflavin $\left(\mathrm{B}_{2}\right)$ pantothenic acid, biotin and vitamin $\mathrm{E}$. If biotin is deficient, it can cause skeleton deformities and bent beak. Riboflavin deficiency causes muscle atrophy, short legs, bleeding, edema, anemia and mortality peaks from the 9th to the 14th day;

- Zinc-methionine, manganese-methionine and copper-methionine: manganese deficiency during embryonic development can cause severe skeletal abnormalities, while zinc deficiency causes abnormalities in the head, limbs and vertebrae and copper is required for enzyme activities associated with iron and elastin metabolism, bone collagen formation, melanin production and integrity of the central nervous system.

At the end of incubation, the embryo requires a great amount of glucose as energy source for the outbreak and this carbohydrate supply is primarily achieved from the glycogenolysis of glycogen stores and afterwards the protein by gluconeogenesis (Uni et al., 2005). Researches shows that egg via supplementation with maltose plus sucrose and other carbohydrates promote lower use of liver glycogen reserves and muscle protein from embryos (Uni, 2003; Tako et al., 2004; Uni et al., 2005).

Contradictory results were found by Leitão et al. (2008), where glucose supplementation in low-weight eggs did not stimulate the intestinal development, not thereby improving the chicks' performance in early phase. According to Tako et al. (2004), better results are obtained when using disaccharides (maltose, sucrose) for in-egg supplementation, which provides stimulus for enzymes synthesis and, consequently, higher absorption of nutrients

According to Uni (2003), the embryo orally consumes the amniotic fluid, thus when supplemented via allantoiccavity, nutrients are available in the digestive system where absorption occurs. Chicks from eggs supplemented with maltose, sucrose and dextrin (Tako et al., 2004) showed greater length and width of villi than those from nonsupplemented eggs. Uni (2003) observed an increase in enteric development and newly hatched chicks that received in-egg carbohydrate had gastrointestinal tract functionally similar to a two-day age chick without supplementation.

Studies conducted with carbohydrate inoculation, using a technique that runs through the air-tube, caused a higher embryos mortality than the directly inoculation into the allantoic cavity.

Inoculation of either nutrients or additives "in egg” can be very efficient in the search for better production indices in the poultry industry. However, it is still need further studies to better assess its use feasibility in both research and industrial scale.

\section{Molecular biology}

Molecular biology has become economically viable the use of exogenous enzymes that act in the digestion of certain nutrients in plant foods that are not metabolized by endogenous enzymes. Examples of biotechnology application would be to increase the nutritional capacity as well as the expression of phytase, or resistance to certain diseases.

The molecular biology techniques allow the assessment of deoxyribonucleic (DNA) and ribonucleic (RNA) acids which assists in the identification and characterization of mutations that occur during the evolution and adaptability of species. The molecular marker is a gene, a restriction site or any other DNA characteristic that allows to distinguish differences among individuals. The use of molecular biology, especially the technique of polymerase chain reaction (PCR), uses a thermostable DNA polymerase facilitating the detection of genetic polymorphisms in the DNA directly.

Some PCR variations led to development of other techniques that allow the analysis of genetic diversity, such as RAPD (random amplified DNA polymorphism), SSR (or microsatellites - short sequences repeated in series), SNPs (single nucleotide polymorphism) SAMPL (selective amplification of microsatellite polymorphic loci) and AFLP (amplified fragment length polymorphism).

Studies on DNA polymorphisms are important by being associated with traits of economic interest; therefore, basic studies on techniques for extracting high quality DNA are crucial for research development in molecular biology (Sollero et al., 2004).

Several groups of researchers are engaged in developing genomic maps in different animal species, among which are highlighted: cattle, poultry and swine. The objective is to obtain molecular markers for all chromosomes, allowing 
that the genetic potential of an animal is determined even before its phenotype expression, ie, without assessing its production or its progeny. The swine industry has extensively used the information generated by genomic markers in combination with traditional performance information to increase production through marker-assisted selection.

\section{Final Considerations}

It is expected that in coming years the production of monogastrics reach even greater heights of development than the actual future projections. In this context the importance of ongoing research focused on animal nutrition is undeniable.

More scientific discoveries in the fields of genetics, health, management and ambience will continue leveraging the growth in production of monogastric animals, corroborating with even higher rates of productivity, but not forgetting that the main goal of this whole development is the quality food production.

Thus, for the twenty-first century, it is presupposed that we will have not only economic and productive good indices in the areas of poultry and swine, but also products with nutritional quality, safe for human consumption and meeting national and international markets which are increasingly demanding.

\section{References}

ALBINO L.F.T.; FERES F.A.; DIONIZIO M.A. et al. Uso de prebióticos à base de mananoligossacarídeo em rações para frangos de corte. Revista Brasileira de Zootecnia, v.35, n. 3,742-749, 2006.

ASSOCIAÇÃO BRASILEIRA DA INDÚSTRIA PRODUTORA E EXPORTADORA DE CARNE SUÍNA - ABIPECS [2009]. 2009, um ano difícil para a produção de carne suína. Disponível em < http://www.abipecs.org.br > Acesso em: 2/3/2010.

AVICUlTURA INDUSTRIAL [2009]. Análise de mercado. Disponível em < http:// www.aviculturaindustrial.com.br > Acesso em: $2 / 3 / 2010$

AVICULTURA INDUSTRIAL [2010]. Futuro da genética. Disponível em < http:// www.aviculturaindustrial.com.br > Acesso em: $14 / 3 / 2010$.

ARAÚJO, L.F.; JUNQUEIRA, O.M.; ARAÚJO, C.S.S. et al. Proteína bruta e proteína ideal para frangos de corte no período de 1 a 21 dias de idade. Revista Brasileira de Ciência Avícola, v.3, n.2, p.157-162, 2001.

AWAD, W.A.; GHAREEB, K.; ABDEL-RAHEEM, S. et al. Effects of dietary inclusion of probiotic and symbiotic on growth performance, organ weights and intestinal histomorphology of broiler chickens. Poultry Science, v.88, p.49-56, 2009.

BARCELLOS, D.E.S.N.; MORES, T.J.; SANT, M. et al. Avanços em programas de biosseguridade para a suinocultura. Acta Scientiae Veterinariae, v.36 (Supl 1), p.33-46, 2008.

BATTERHAM, E.S. Protein and energy relationship for growing pigs. In: COLE, D.J.A.; WISEMAN, J.; VARLEY, M.A. (Eds.)
Principles of pig science. Nottingham: Nottingham University Press, 1994. p.107-121.

BELLAVER, C. O uso de microingredientes (aditivos) na formulação de dietas para suínos e suas implicações na produção e na segurança alimentar. In: CONGRESSO MERCOSUL DE PRODUÇÃO SUÍNA, 1., 2000, Buenos Aires. Anais... Buenos Aires: FCV/UBA, FAV/UNRC, EMBRAPA, 2000. p.93-108.

BELLÉ, J.C.; SILVA, C.A.; BRIDI, A.M. et al. Avaliação de prebióticos como promotor de crescimento para suínos nas fases de recria e terminação. Semina: Ciências Agrárias, v.30, n.2, p.471-480, 2009.

BIEGELMEYER, P.; PROVENCI, M.; MANZKE, N.E. et al. Inclusão de extrato de leveduras na dieta inicial de poedeiras e seu efeito sobre a qualidade dos ovos. In: XVIII CIC. XI ENPOS. I Mostra Científica. 2009.

BORATTO, A.J.; LOPES, D.C.; OLIVEIRA, R.F.M. et al. Uso antibióticos, de probióticos e de homeopatia, em frangos de corte criados em ambiente de conforto, inoculados ou não com Escherichia coli. Revista Brasileira de Zootecnia, v.33, n.6, p.1477-1485, 2004.

BORGES, C.A. [2009]. Avanços nutricionais para otimização de resultados na avicultura. Disponível em: <http:// pt.engormix.com/MA-avicultura/nutricao/artigos/avancosnutricionais-otimizacao-resultados_143.htm>. Acesso em: 7/3/2010.

BREGENDAHL, K.; SELL, J.L.; ZIMMERMAN, D.R. Effect of low-protein diets on growth performance and body composition of broiler chicks. Poultry Science, v.81, p.1156-1167, 2002.

BRITO, J.A.G. [2010]. Um conceito moderno e aplicado em nutrição de aves e suínos. Disponível em: <http:// www.suinoculturaindustrial.com.br/PortalGessulli/ WebSite/ Noticias/um-conceito-moderno-e-aplicado-em-nutricao-deaves-e-suinos,201 00212100818_X_924,20081118093828 _H_824.aspx> Acesso em: 7/3/2010.

BURKETT, J.L.; STALDER, K.J.; SCHWAB, C.R. et al. Growth comparison and fecal mineral excretion of inorganic and organic trace mineral supplementation in swine. Iowa State University Animal Industry Report, p.8, 2005.

BURNHAM, M.R.; PEEBLES, E.D.; GARDNER, C.W. et al. Effects of incubator humidity and hen age on yolk compositions in broiler hatching eggs from young breeders. Poultry Science, v.80, n.10, p.1444-1450, 2001.

CAMPESTRINI, E.; SILVA, V.T.M; APPELT, M.D. Utilização de enzimas na alimentação animal. Revista Eletrônica Nutritime, v.2, n.6, p.254-267, 2005

CARVALHO, L.E.; MANSO, H.E.C.; NEPOMUCENO, R.C. et al. Suplementação com glutamina em porcas primíparas no terço final da gestação e período de lactação sobre a prolificidade no parto seguinte. In: CONGRESSO BRASILEIRO DE NUTRIÇÃO ANIMAL, 1., 2008, Fortaleza. Anais...Fortaleza: Congresso Brasileiro de Nutrição Animal, [2008]. (CD-ROM).

COLE, D.J.A.; VAN LUNEN, T.A. Ideal amino acid patterns. In: D’MELLO, J.P.F. (Ed.) Amino acids in farm animal nutrition. Wallingford: CAB International, 1994. p.99-112.

COSTA, F.G.P.; ROSTAGNO, H.S.; ALBINO, L.F.T. et al. Níveis dietéticos de proteína bruta para frangos de corte de 1 a 21 e 22 a 42 dias de idade. Revista Brasileira de Zootecnia, v.30, p.1498-1505, 2001.

COSTA, F.G.P.; SILVA, J.H.V.; GOULART, C.C. et al. O Zootecnista e as biotecnologias em nutrição de aves e suínos. Anais eletrônicos... João Pessoa: Zootec, 2008a. (CD-ROM).

COSTA, F.G.P.; NOBRE, I.S.; GOULART, C.C. et al. Utilization of prebiotic in laying quails (Coturnix coturnix japonica) diet. In: ALLTECH INTERNATIONAL ANIMAL HEALTH AND NUTRITION SYMPOSIUM, 24., 2008, Lexington. Proceedings... Lexington: Alltech, [2008b], (CD-ROM).

COSTA, F.G.P.; GOULART, C.C.; NOGUEIRA, E.T. et al. Valine, isoleucine, and glycine in reduced-protein prestarter broiler feeds, In: POULTRY SCIENCE ASSOCIATION ANNUAL 
Meting, 98., 2009, Raleigh. Anais... Raleigh: Poultry Science, [2009a]. (CD-ROM).

COSTA, F.G.P.; GOULART, C.C.; NOGUEIRA, E.T. et al. Effects of crude protein levels and essential amino acids: nonessential amino acids ratio on broiler carcasses. In: POULTRY SCIENCE ASSOCIATION ANNUAL MEETING, 98., 2009, Raleigh. Proceedings... Raleigh: Poultry Science, [2009b]. (CD-ROM).

COSTA, F.G.P.; MORAIS, S.A.N.; NOGUEIRA, E.T. et al. Digestible valine: digestible lysine ratio for broilers in the growing phase. In: INTERNATIONAL POULTRY SCIENTIFIC FORUM, 2010, Georgia. Proceedings... Georgia: POULTRY SCIENTIFIC, 2010a. (CD-ROM).

COSTA, F.G.P.; RODRIGUES, V.P.; GOULART, C.C. et al. Diet formulation based on digestible amino acids to Japanese quail for 1 to 21 days. In: INTERNATIONAL POULTRY SCIENTIFIC FORUM, 2010, Georgia. Proceedings... Georgia: POULTRY SCIENTIFIC, 2010b. (CD-ROM).

COSTA, F.G.P.; GOULART, C.C.; FIGUEIREDO-LIMA, D.F. et al. Crude protein and essential: non-essential amino acids ratio for broiler chickens from 8 to 21 days. In: INTERNATIONAL POULTRY SCIENTIFIC FORUM, 2010, Georgia. Proceedings... Georgia: POULTRY SCIENTIFIC, 2010c. (CD-ROM).

COSTA, F.G.P.; GOULART, C.C.; FIGUEIREDO-LIMA, D.F. et al. Crude protein and essential: non-essential amino acids ratio for broiler chickens from 22 to 40 days. In: INTERNATIONAL POULTRY SCIENTIFIC FORUM, 2010, Georgia. Proceedings... Georgia: POULTRY SCIENTIFIC, 2010d. (CD-ROM).

COSTA, F.G.P.; SANTOS, T.T.; SUIDA, D. et al. Use of xylanase and phytase with fat (linoleic acid) levels different in broiler feeds from 1 to 21 days. In: INTERNATIONAL POULTRY SCIENTIFIC FORUM, 2010, Georgia. Proceedings... Georgia: POULTRY SCIENTIFIC, 2010e. (CD-ROM).

COSTA, F.G.P.; OLIVEIRA, C.F.S.; MOURA, B.H.A. et al. Effects of exogenous enzymes (Allzyme ${ }^{\circledR}$ SSF and Allzyme Vegpro ${ }^{\mathrm{TM}}$ ) on performance of semi-heavy layers at peak production. In: In: INTERNATIONAL POULTRY SCIENTIFIC FORUM, 2010, Georgia. Proceedings... Georgia: POULTRY SCIENTIFIC, 2010f. (CD-ROM).

CRUZ, V.C.; PELÍCIA, V.C.; SARTORI, J.R. et al. Efeito da adição de nucleotídeos na dieta sobre o perfil bioquímico sanguíneo de frangos de corte alternativos. In: ENCONTRO DE ZOOTECNIA, 5., SIMPÓSIO DE CIÊNCIAS DA UNESP, 4., 2008, Dracena. Anais... Dracena: Unesp, [2008].

DEAN, D.W.; BIDNER, T.D.; SOUTHERN, L.L. Glycine supplementation to low protein, amino acid-supplemented diets supports optimal performance of broiler chicks. Poultry Science, v.85, p.288-296, 2006.

DIBNER, J.J.; RICHARDS, J.D. Antibiotic growth promoters in agriculture: history and mode of action. Poultry Science, v.84, p.634-643, 2005.

EDQVIST, L.; PEDERSEN, K.B. Antimicrobials as growth promoters: resistence to common sense. In: HARREMOES, P.; GEE, D.; MACGARVIN, M. et al. (Eds.) Late lessons from early earnings: the precautionary principle 1896-2000. Copenhagen: European Environment Agency, 2001.p.64-72 (Environment Issue Report, 22).

EMPRESA BRASILEIRA DE PESQUISA E AGROPECUÁRIA EMBRAPA. [2004]. Disponível em < www.cnpsa.embrapa.br > Acesso em: 13/3/2010.

ESTEVE-GARCIA, E.; MARTÍNEZ-PUIG, D.; BORDA, E. et al. Efficacy of a nucleotide preparation in broiler chickens In: EUROPEAN SYMPOSIUM ON POULTRY NUTRITION. Proceedings... Strasbourg: World's Poultry Science Association, 2007.

FERKET, P.; OLIVEIRA, J.; GHANE, A. et al. Effect of in ovo feeding solution osmolality on hatching turkeys. In: INTERNATIONAL POULTRY SCIENTIFIC FORUM, 2005,
Atlanta. Abstracts... Atlanta: Poultry Science Association, 2005a. p.28.

FERNANDES, J.I.M.; MURAKAMI, A.E.; SAKAMOTO M.I. et al. Effects of organic mineral dietary supplementation on production performance and egg quality of white layers. Revista Brasileira de Ciência Avícola, v.10, n.1, p.59-65, 2008.

FILHO, R.L.A.F.; PATRÍCIO, I.S. Biosseguridade da granja de frangos de corte. In: MENDES, A.A.; NAAS, I.A.; MACARI, M. (Eds.) Produção de frangos de corte. Jaboticabal, 2004. p.169-177.

FREMAUT, D. Trace mineral proteinates in modern pig production: reducing mineral excretion without sacrificing performance. In: NUTRITIONAL BIOTECHNOLOGY IN THE FEED AND FOOD INDUSTRIES, 2003. Proceedings... Alltech's Nineteenth Annual Symposium, 2003. p.171-178.

GOULART, C.C. Exigências de aminoácidos industriais e relação aminoácidos essenciais: não essenciais em dietas para frangos de corte. 2010. 148f. Tese (Doutorado em Zootecnia) - Universidade Federal da Paraíba, Areia.

HAESE, D.; SILVA, B.A.N. Antibióticos como promotores de crescimento em monogástricos. Revista Eletrônica Nutritime, v.1, n.1, p.7-19, 2004.

HAN, Y.; SUZUKY, H.; PARSONS, C.M. et al. Amino acid fortification of a low-protein corn and soybean meal diets for chicks. Poultry Science, v.71, n.7, p.1168-1178, 1992.

HAVENSTEIN, G.B.; FERKET, P.R.; QURESHI, M.A. Carcass composition and yield of 1957 versus 2001 broilers when fed "typical" 1957 and 2001 broiler diets. Poultry Science, v.82, p.1509-1518, 2003.

HUSSEIN, A.S.; CANTOR, A.H.; PESCATORE, J. et al. Effect of low protein diets with amino acid supplementation on broiler growth. Journal of Applied Poultry Research, v.10, n.2, p.354-362, 2001

IJI, P.A.; TIVEY, D.R. Natural and synthetic oligosaccharides in broiler chicken diets. Worlds Poultry Science Journal, v.54, p. 129-143, 1998.

IJI, P.A.; SAKI, A.A.; TIVEY, D.R. Intestinal development and body growth of broiler chicks on diets supplemented with nonstarch polysaccharides. Animal Feed Science and Technology, v.89, p.175-188, 2001.

JUNQUEIRA, O.M.; BARBOSA, L.C.G.S.; PEREIRA, A.A. et al. Uso de aditivos em rações para suínos nas fases de creche, crescimento e terminação. Revista Brasileira de Zootecnia, v.38, n.12, p.2394-2400, 2009.

KIKUCHI, C.G.; SAKAMOTO, M.I.; NAKAGI, V.S. et al. [2009] Suplementação de glutamina pura e associada com ácido glutâmico nas fases pré-inicial e inicial de frangos de corte: Desempenho de 1 a 42 dias. Disponível em <http:// www.usp.br/siicusp> Acesso em: 20/3/2010.

KLASING, K.C. Comparative avian nutrition. Universidade de Michigan: Cab International, 1998. 350p.

LARSON, C.K. Role of trace minerals in animal production. [2005]. Disponível em <http://www.tennesseenutritionconference.org/ pdf/.../ConnieLarsen.pdf> Acesso em: 1/3/2010.

LEITÃO, R.A.; LENDRO, N.S.M.; PEDROSO, A.A. et al. Efeito da suplementação de glicose in ovo sobre o desempenho inicial de pintos de corte. Revista Brasileira de Ciência Avícola, v.7, p.69, 2005.

LEITÃO, R.A.; LEANDRO, N.S.M.; STRINGHINI, J.H. et al. Inoculção de glicose em ovos embrionados de frango de corte: parâmetros de incubação e desempenho inicial. Ciência Animal Brasileira, v.9, n.4, p.847-855, 2008.

LIMA, M.R.; BARROSO, J.F.; COSTA, F.G.P. et al. Efeito dose resposta de fitase para ração farelada sobre o desempenho de poedeiras. In: CONGRESSO BRASILEIRO DE AVICULTURA, 21., 2009, Porto Alegre. Anais... Porto Alegre: 2009a.

LIMA, M.R.; BARROSO, J.F.; COSTA, F.G.P. et al. Efeito dose resposta de fitase para ração farelada sobre o desempenho de 
poedeiras - Análise econômica. In: CONGRESSO BRASILEIRO DE AViculturA, 21., 2009, Porto Alegre. Anais... Porto Alegre: 2009b.

LIMA NETO, R.C. Níveis de treonina, glicina+serina e suas relações para pintos de corte. Tese (Doutorado em Programa de Doutorado Integrado em Zootecnia) - Universidade Federal da Paraíba, 2010

LODDI, M.M.; GONZALES, E.; TAKITA, T.S. et al. Uso de probiótico e antibiótico sobre o desempenho, o rendimento e a qualidade da carcaça de frangos de corte. Revista Brasileira de Zootecnia, v.29, n.4, p.1124-1131, 2000.

LOPES, D.C.E.; ROSTAGNO, H.S. [2007]. Desempenho e morfologia intestinal de leitões alimentados com Aminogut ${ }^{\circledR}$ e plasma. Aminogut ${ }^{\circledR}$ Ciência e Prática na Nutrição de Leitões (Boletim Especial Ajinomoto). Disponível em $<$ http:// www.lisina.com.br/publicacoes.aspx> Acesso em: 20/3/2010.

McLEOD, M. Effects of amino acid balance and energy: protein ratio on energy and nitrogen metabolism in male broiler chicken. British Poultry Science, v.38, p.405-411, 1997.

MENG, X.; SLOMINSKI, B.A.; NYACHOTI, C.M. et al. Degradation off cell wall polisaccharides by combination of carbohydrase enzymes and their effect on nutrient utilization and broiler chicken performance. Poultry Science, v.84, p.37-47, 2005.

MINISTÉRIO DA AGRICULTURA - MAPA [2004]. Departamento de fomento e fiscalização da Produção animal. Disponível em < http://www.anvisa.org > Acesso em: 4/3/2010.

MORAIS, S.A.N.; COSTA, F.G.P.; NOGUEIRA, E.T. et al.Digestible valine: Digestible lysine ratio for broilers chickens in the initial phase. In: INTERNATIONAL POULTRY SCIENTIFIC FORUM, 2010, Georgia. Proceedings... Georgia: POULTRY SCIENTIFIC, [2010]. (CD-ROM).

MOUNTZOURIS, K.C.P.; TSISTSIKOS, E.; KALAMARA, S. et al.Evaluation of the efficacy of a probiotic containing Lactobacillus, Bifidobacterium, Enterococcus, and Pediococcus strains in promoting broiler performance and modualting cecal microflora composition and metabolic activities. Poultry Science. v.86, p.309-317, 2007.

MURAKAMI, A.E.; FERNANDES, J.I.M.; SAKAMOTO, M.I. et al. Efeito da suplementação enzimática no desempenho e qualidade dos ovos de poedeiras comerciais. Acta Scientarium Animal Science, v.29, n.2, p.165-172, 2007.

MURAROLLI, V.D.A. Efeito de prebiótico, probiótico e simbiótico sobre o desempenho, morfologia intestinal e imunidade de frangos de corte. 2008. 101f. Dissertação (Mestrado em Medicina Veterinária) - Centro de Ciências Agrárias da Universidade de São Paulo, Pirassununga.

NAGATA, A.K.; RODRIGUES, P.B.; RODRIGUES, K.F. et al. Energia metabolizável e proteína ideal para frangos de corte de 1 a 21 dias de idade, utilizando aminoácidos sintéticos e fitase. Revista Brasileira de Ciência Avícola, v.7, p.85, 2005a.

NAGATA, A.K.; RODRIGUES, P.B.; RODRIGUES, K.F. Níveis de energia metabolizável e proteína bruta em rações suplementadas com fitase e aminoácidos sintéticos para frangos de corte no período de 22 a 42 dias de idade. In: REUNIÃO ANUAL DA SOCIEDADE BRASILEIRA DE ZOOTECNIA, 42., 2005, Goiânia - GO. Anais... Goiânia: SBZ, 2005b. (CD-ROM).

NATIONAL RESEARCH COUNCIL - NRC. Nutrient requirements of poultry. 9.ed. Washington, D.C.: National Academy of Science, 1994. 155p.

OLIVEIRA, A.S. Minerais quelatados. [2004]. Disponível em:< h t t p : / / w w w. re hag ro. co m. b r/sit e re hag ro/ publicacao.do?cdnoticia=472> Acesso em: 7/3/2010.

OLIVEIRA, M.C.; CANCHERINI, L.C.; MARQUES, R.H. et al. Mananoligossacarídeos e complexo enzimático em dietas para frangos de corte. Revista Brasileira de Zootecnia, v.38, n.5, p.879-886, 2009.

OVIEDO-RONDON, E.O. Molecular methods to evaluate effects of feed additives and nutrients in poultry gut microflora. Revista Brasileira de Zootecnia, v.38, p.209-225, 2009.
PARSONS, C.M., BAKER, D.H. The concept and usage of ideal proteins in the feeding of non ruminants. In: SIMPÓSIO INTERNACIONAL DE PRODUÇÃO DE NÃO RUMINANTES, 1994, Maringá. Anais... Maringá: EDUEM, 1994. p.119-128.

PEREIRA, A.A.; JUNQUEIRA, O.M.; PRAES, M.F.F.M. Avicultura e meio ambiente [2009]. Disponível em: <http:// www.aveworld.com.br /noticia_imprimir .php?cod=7314> Acesso em: 7/3/2010.

PENZ JR., A.M. O conceito de proteína ideal para monogástricos. In: CONGRESSO NACIONAL DE ZOOTECNIA, 1996, Porto Alegre. Anais... Porto Alegre, [s.n.], 1996. p.71-84.

PINCHASOV, Y.; MENDONÇA, C.X.; JENSEN, L.S. Broiler chick response to low protein diets supplemented with synthetic amino acids. Poultry Science, v.69, p.1950-1955, 1990.

PUPA, J.M.R. Saúde intestinal dos leitões: o papel de alguns agentes reguladores. In: SIMPÓSIO BRASIL SUL DE SUINOCULTURA, 2008, Chapecó. Anais... Chapecó: Embrapa Suínos e Aves, 2008. 129p.

ROCHA, J.S.R.; LARA, L.J.C.; BAIÃO, N.C. Aspectos éticos e técnicos da produção intensiva de aves. Ciência Veterinária nos Trópicos, v.11, supl.1, p.49-55, 2008.

RODRIGUES, V.P.; COSTA, F.G.P; SOUZA, R.B. et al. Diet formulation based on digestible amino acids to Japanese quail for 22 to 42 days. In: INTERNATIONAL POULTRY SCIENTIFIC FORUM, 2010, Georgia. Anais... Georgia: POULTRY SCIENTIFIC, [2010]. (CD-ROM).

ROPPA, L. Atualização sobre os níveis de colesterol, gordura e calorias da carne suína. In: REUNIÃO ANUAL DA SOCIEDADE BRASILEIRA DE ZOOTECNIA, 36., 1999, Porto Alegre. Anais... Sociedade Brasileira de Zootecnia, 1999. (CD-ROM).

RODRIGUES, P.B.; FREITAS, R.T.F.; FIALHO, E.T. et al. Digestibilidade dos nutrientes e desempenho de suínos em crescimento e terminação alimentados com rações à base de milho e sorgo suplementadas com enzimas. Revista Brasileira de Milho e Sorgo, v.1, n.2, p.91-100, 2002.

ROSTAGNO, H.S, PAEZ, L.E, TOLEDO, R.S. et al. Actualización de La nutrición de aminoácidos y proteína em pollos de engorde. In: SEMINÁRIO LATINO AMERICANO DE AVICULTURA, 17., 2002, Habana. Anais... Habana: 2002. p.16.

ROSTAGNO, H.S.; ALBINO, L.F.T.; DONZELE, J.L. et al. Tabelas brasileiras para aves e suínos: composição de alimentos e exigências nutricionais. 2.ed. Viçosa, MG: Universidade Federal de Viçosa, 2005.

RUTZ, F.; XAVIER, E.G.; RECH, J.L. et al. Os nucleotídeos são nutrientes essenciais? Níveis de inclusão e efeitos sobre o desempenho animal. In : RONDA LATINO AMERICANA DA ALLTECH, 16., 2006, Maringá. Anais... Maringá: Alltech São Pedro, 2006. v.1. 52p.

RUTZ, F.; PAN, E.A.; XAVIER, G.B. [2007] Efeito de minerais orgânicos sobre o metabolismo e desempenho de aves. Revista Aveworld. Disponível em <http:// www.aveworld.com.br/index.php/documento/141.> Acesso em: 7/3/2010.

RUTZ, F.; GONÇALVES, F.M.; ANCIUTI, M.A. et al. Nutrigenômica na produção de aves e suínos. [2009]. Disponível em <www.avisite.com.br> Acesso em: 14/3/2010.

SAKOMURA, N.K; ROSTAGNO, H.S. Métodos de pesquisa em nutrição de monogástricos. Jaboticabal: Funep, 2007. 283p.

SELLE, P.H; RAVINDRAN, V. Microbial phytase in poultry nutrition. Animal Feed Science and Technology, v.135, p.1-41, 2007.

SHANE, S.M. Mannanoligosaccharides in poultry nutrition: mechanisms and benefits. In: ALLTECH'S ANNUAL SYMPOSIUM, 17., 2001, Lexington. Proceedings... Lexington: Alltech, 2001. p.65-77.

SILVA, D.J.; QUEIRÓZ, A.C.D. Análises de alimentos: métodos químicos e biológicos. 3.ed. Viçosa, MG: UFV, 2004. 235p.

SILVA, V.K. et al. Desempenho de frangos de corte de 1 a 21 dias de idade alimentados com rações contendo extrato de leveduras 
e prebiótico e criados em diferentes temperaturas. Revista Brasileira de Zootecnia, v.38, n.4, p.690-696, 2009.

SILVA, J.H.V.; COSTA, F.G.P. Tabelas para codornas japonesas e européias. Editora: FUNEP, 2009. 107p.

SIMS, M.D.; DAWSON, K.A.; NEWMAN, K.E. et al. Effects of dietary mannan oligosaccharide, bacitracin methylene disalicylate, or both on the live performance and intestinal microbiology of turkeys. Poultry Science, v.83, p.11481154, 2004.

SOLLÉRO, B.P.; FARIA, D.A.; PAIVA, S.R. et al. Método rápido de extração de DNA utilizando CTAB em tecidos musculares de suínos. Anais eletrônicos... Brasília: ZOOTEC, 2004.

STANLEY, V.G.; KRUEGER, W.F.; SEFTON A.E. Single and combined effects of yeast cell wall residue and Sel-Plex on production and egg quality of laying hens. Poultry Science, v.83, p. 260, 2004.

STUTZ, M.W.; LAWTON, G.C. Effects of diet and antimicrobials on growth, feed efficiency, intestinal Clostridium perfringens, and ileal weight of broiler chicks. Poultry Science, v.63, p.2036-42,1984.

SUIDA, D. Formulação por proteína ideal e conseqüências técnicas, econômicas e ambientais. In: SIMPÓSIO INTERNACIONAL DE NUTRIÇÃO ANIMAL: PROTEÍNA IDEAL, ENERGIA LÍQUIDA E MODELAGEM, 2001, Santa Maria. Anais... Santa Maria: EMBRAPA, 2001. p.27-43.

SKLAN, D.; GEYRA, A.; TAKO, E. et al. Ontogeny of brush border carbohydrate digestion and uptake in the chick. British Journal of Nutrition, v.89, n.6, p.747-753, 2003.

TAKO, E.; FERKET, P.R.; UNI, Z. Effects of in ovo feeding of carbohydrates and $\beta$-hidroxy- $\beta$-methylbutyrate on the development of chicken intestine. Poultry Science, v.83, n.12, p.2023-2028, 2004.
TIBBETS, G.W. Nucleotídeos presentes no extrato de levedura de cepa específica:alternativa para substituição de fontes protéicas de origem animal. Pork World, p.36-39, 2004.

TUCKER, L.A. Organic minerals may change nutritional needs. World Poultry, v.9, p.16-17, 2004.

UNI, Z. Methods for early nutrition and their potential. In: EUROPEAN SYMPOSIUM OF POULTRY NUTRITION, 2003, Lillehammer. Proceedings... Lillehammer: World Poultry Science Association, 2003. p.254-260.

UNI, Z; FERKET, P.R.; TAKO, E. et al. In ovo feeding improves energy status of late-term chicken embryos. Poultry Science, v.84, n.5, p.764-770, 2005.

UTIYAMA, C.E.; OETTING, L.L.; GIANI, P.A. et al. Efeitos de antimicrobianos, prebióticos, probióticos e extratos vegetais sobre a microbiota intestinal, a freqüência de diarréia e o desempenho de leitões recém-desmamados. Revista Brasileira de Zootecnia, v.35, n.6, p.2359-2367, 2006.

VITS, A.; WEITZENBURGER, D.; HAMANN, H. Production, egg quality, bone strength, claw length, and keel bone deformities of laying hens housed in furnished cages with different group sizes. Poultry Science, v.84, p.1511-1519, 2005.

WALDROUP, P.W.; JIANG, Q.; FRITTS, C.A. Effects of glycine and threonine supplementation on performance of broiler chicks fed diets low in crude protein. International Journal of Poultry Science, v.4, n.5, p.250-257, 2005.

YI, G.F.; CARROLL, J.A.; ALLEE, G.L. et al. Effect of glutamine and spray-dried plasma on growth performance, small intestinal morphology, and immune responses of Escherichia coli K88+challenged weaned pigs. Journal Animal Science, v.83, p.634643, 2005.

ZUANON, J.A.S.; FONSECA, J.B.; ROSTAGNO, H.S. et al. Efeito de promotores de crescimento sobre o desempenho de frangos de corte. Revista Brasileira de Zootecnia, v.27, p.9991005, 1998. 